\title{
Save the date for EUROSON 2015
}

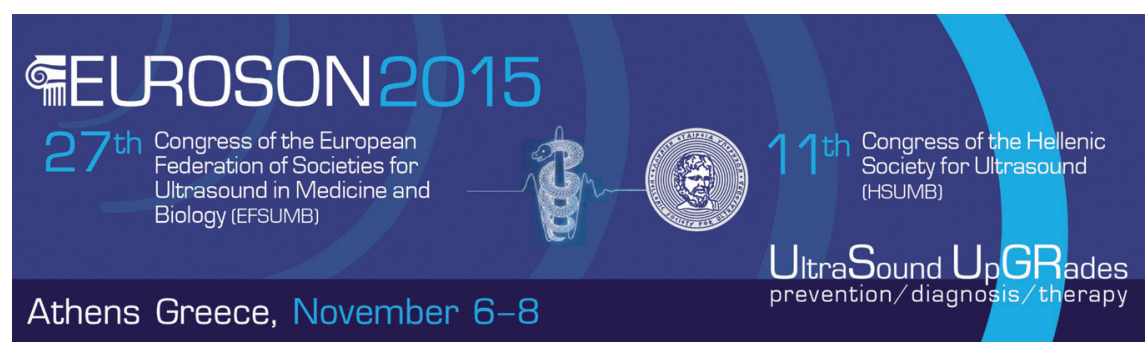

